\title{
Detecting Earning Management of Companies Listing on HOSE
}

\author{
Vo Thi Quy ${ }^{1}$ \\ Duong Trong Nhan ${ }^{2}$
}

The Faculty of Business Administration International University, Vietnam

The Faculty of Accounting Department Ho Chi Minh City Open University Ho Chi Minh City, Vietnam

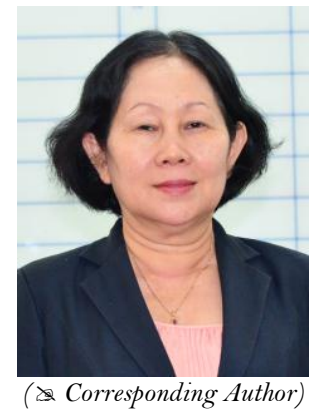

\begin{abstract}
The study is aimed to detecting earning management from companies listing in Ho Chi Minh Stock Exchange (HOSE) during the period from 2013 - 2015 by using 2 models, Jones (1991) and Modified Jones Model developed by Dechow et al. (1995). Moreover, we also tested the effectiveness of Jones (1991) for detecting firms' earning management since prior researches showed that Jones (1991) has lower standard error in detecting accruals based earning management compared with other models as suggested by DeAngelo et al. (1994). Hence we proposed that Jones (1991) provides a more significant outcome for estimating the nondiscretionary component of accruals and thus less exposed to misspecifications error from absent variables. We found that Jones (1991) illustrates a better explainable ability even though the adjusted R-square of the models is closely similar with each other.
\end{abstract}

Keywords: Earning Management, Jones Model, Modified Jones Model, HOSE.

Citation | Vo Thi Quy; Duong Trong Nhan (2017). Detecting Earning Management of Companies Listing on HOSE. Asian Journal of Social Sciences and Management Studies, 4(2): 82-87. History:

Received: 16 May 2017

Revised: 7 June 2017

Accepted: 14 June 2017

Published: 20 June 2017

Licensed: This work is licensed under a Creative Commons Attribution 3.0 License (c) $\mathbf{E Y}$

Publisher:Asian Online Journal Publishing Group
Contribution/Acknowledgement: Both authors contributed to the conception and design of the study.

Funding: This study received no specific financial support.

Competing Interests: The authors declare that they have no conflict of interests.

Transparency: The authors confirm that the manuscript is an honest, accurate, and transparent account of the study was reported; that no vital features of the study have been omitted; and that any discrepancies from the study as planned have been explained.

Ethical: This study follows all ethical practices during writing.

\section{Contents}

1. Introduction

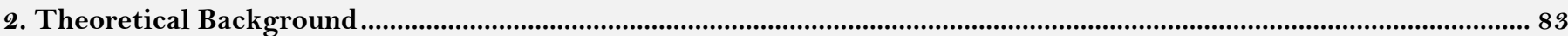

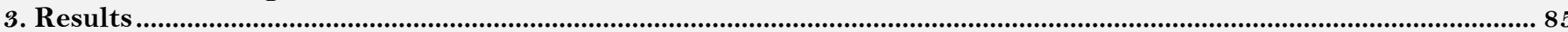

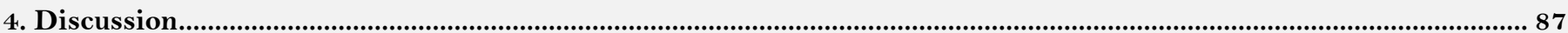

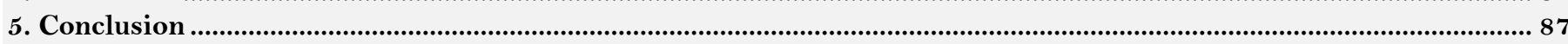

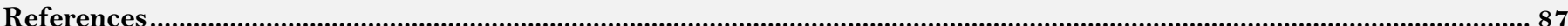




\section{Introduction}

Earnings management has been gaining a lot of attention recently. Earnings management is characterized as the adjustment of firms' financial statements and actual economic performance by insiders or administrators to either "deceive some stakeholders" or to "control contractual outcomes" (Healy and Wahlen, 1999). Many studies about earning management proposed that managers process manipulation to their reported earnings to match their motives by adapting certain company's accounting procedure, altering accounting estimation, and/or managing accruals. Earnings management is able to create unfavorable consequences for the value of the companies in the long term. Previous studies found that firms involving in earnings management to meet and/or overcoming analyst predictions have benefited from a rising stock price, but this advantage appears only for a short term. For the long term, the performance and share price of those companies involved in managing earnings are less sustainable than enterprises that did not employ earning management technique (Bhojraj et al., 2009). Earnings management also creates an apparent disadvantage for financial information users like external stakeholders who faced an asymmetric information problem and count on the financial report to come up with final decisions in order to make important investment (Burns and Merchant, 1990). The act of manipulating earnings also contravenes the accounting's practical code of professional. Managing earning can violate the relevant rules of accounting. For example, the act of successful manipulation to cover earning adjustments, disguising a failure to meet or exceed forecasted profit by financial analyst, changing a loss into profit or vice versa (Grant et al., 2000). Earning management has been gaining more attention since the fraudulent scandal of Enron and WorldCom were exposed and judged as an unethical action of manipulating earning management.

There are many popular and well known models developed by Healy (1985); DeAngelo (1986); Jones (1991); Patricia et al. (1995) and Kothari et al. (2005) used to identify and investigate the actions of manipulating earnings management of firm managers, but in Vietnam lacks of such studies, even though the difference between pre- and post-audit earnings of Vietnamese firms listing in Vietnamese stock markets is announced rather regularly, so that we suspect the existence of manipulating earnings management among these firms. Therefore, this study was carried out for identifying the action on earnings management from the listed companies on HOSE, and investigating the effectiveness of Jones (1991).

\section{Theoretical Background}

\subsection{Earning Management Definition}

Earnings management happens when firm managers makes adjustment in reporting financial statement deceive shareholders, investors, creditor and readers of financial report about the actual operating performance of the company or to create an impact on profitable outcomes which rely on reported numbers on financial statement (Healy and Wahlen, 1999).

\subsection{Models for Detecting Accrual Based Earning Management 2.2.1. Healy (1985)}

Healy (1985) studied relationship between earning management and executive compensation, and developed the model to evaluate nondiscretionary as in below equation:

$\mathrm{NDA}_{\mathrm{t}+1}=(1 / \mathrm{n}) \Sigma\left(\mathrm{TAi}, \mathrm{t} / \mathrm{A}_{\mathrm{t}-1}\right)$

Where:

NDA $t+1=$ nondiscretionary accruals for period $t+1$

$\mathrm{TA} i, t=$ total accruals in year $\mathrm{t}$ for firm $\mathrm{i}$

At $-1=$ total assets in year $\mathrm{t}-1$ for the firm $\mathrm{i}$

$\mathrm{n}=$ number of years

Healy model estimates non-discretionary accruals. The discretionary accrual is calculated by subtracting the nondiscretionary accruals from the total accruals from the estimated period.

\subsubsection{Jones (1991)}

Jones (1991) developed the model to detect the accrual based earning management, and become the most widely used model for estimation of earnings management. The model is expressed as below:

$\mathrm{TAi}, \mathrm{t}=\mathrm{Q}_{\mathrm{o}}(1 / \mathrm{Ai}, \mathrm{t}-1)+\mathrm{Q}_{1} \Delta \mathrm{REVi}, \mathrm{t}+\mathrm{Q}_{2} \mathrm{PPEi}, \mathrm{t}+\mathrm{si}, \mathrm{t}$

Where:

$\mathrm{TAi}, \mathrm{t}=$ total accruals in year $\mathrm{t}$ for firm $\mathrm{i}$

$\triangle \mathrm{REVi}, \mathrm{t}=$ revenues in year $\mathrm{t}$ less revenue in year $\mathrm{t}-1$ for firm i scaled by Ai,t-1

$\mathrm{PPEi}, \mathrm{t}=$ gross property, plant and equipment in the year $\mathrm{t}$ for the firm i scaled by Ai,t-1

$\mathrm{Ai}, \mathrm{t}-1=$ total assets in year $\mathrm{t}-1$ for the firm $\mathrm{i}$

$\varepsilon \mathrm{i}, \mathrm{t}=$ error term in the year $\mathrm{t}$ for firm $\mathrm{i}$

Jones (1991) is a linearly related regression approach with the explanatory variables as changes in revenue, and the gross property, plant and equipment, which represent the control for non-discretionary accruals, and regress total accruals. This model was developed with an assumption that all revenues are nondiscretionary and the changes in revenue as a nondiscretionary accrual. Thus, if managers use technique of manipulating revenue, Jones (1991) cannot identify or may underestimate discretionary accruals, according to Ronen and Yaari (2008). Moreover, heteroskedasticity in the model as a big problem; to control the heteroskedasticity, all the variables included, dependent and independent variables, are divided by lagged assets, however, White (1980) stated that heteroskedasticity is reduced by deflation of a variable, but not to be eliminated.

\subsubsection{Modified Jones Model by Dechow et al. (1995)}

The model of Jones (1991) was adjusted by Dechow et al. (1995) for addressing the problems above. The model is specified as below: 
$\mathrm{TAi}, \mathrm{t}=\mathrm{Q}_{0}(1 / \mathrm{Ai}, \mathrm{t}-1)+\mathrm{Q}_{1}(\Delta \mathrm{REVi}, \mathrm{t}-\Delta \mathrm{RECi}, \mathrm{t})+\mathrm{Q}_{2} \mathrm{PPEi}, \mathrm{t}+\varepsilon \mathrm{i}, \mathrm{t}$

Where:

$\mathrm{TAi}, \mathrm{t}=$ total accruals in year $\mathrm{t}$ for firm i scaled by Ai,t-1

$\triangle \mathrm{REVi}, \mathrm{t}=$ revenues in the year $\mathrm{t}$ less revenue in year $\mathrm{t}-1$ for firm i scaled by Ai,t-1

$\triangle \mathrm{RECi}, \mathrm{t}=$ receivables in the year $\mathrm{t}$ less receivables in year $\mathrm{t}-1$ for firm i scaled by Ai,t-1

$\mathrm{PPEi}, \mathrm{t}=$ gross property, plant and equipment in the year $\mathrm{t}$ for the firm i scaled by Ai,t-1

Ai,t-1 = total assets in year $\mathrm{t}-1$ for the firm $\mathrm{i}$

$\varepsilon i, t=$ error term in the year $\mathrm{t}$ for firm $\mathrm{i}$

Change in accounts receivable is accounted for by the changes in revenue because manipulation is the first modification of Dechow et al. (1995). Another effect that the modification caused is cash sales is now adopted in the model because of containing changes in accounts receivable, and this addresses the problems in the Jones (1991).

\subsubsection{Modified Jones Model by Kothari et al. (2005)}

Performance matching model developed by Kothari et al. (2005) improved on the Jones (1991) and the Modified Jones Model by Patricia et al. (1995). The two most well-known models for detect earnings management above are not able to present the correlation between accruals and firm performance because of misspecification in cases of firms that had intense performance (Patricia et al., 1995); (Kothari et al., 2005) debated that operating performance must appear in the equation of discretionary, and thus their model can be used for investigating relation between discretionary accruals and the performance of firms.

$\mathrm{TAi}, \mathrm{t}=\mathrm{Q}_{0}+\mathrm{Q}_{1}(1 / \mathrm{Ai}, \mathrm{t}-1)+\mathrm{Q}_{2} \Delta \mathrm{REVi}, \mathrm{t}+\mathrm{Q}_{3} \mathrm{PPEi}, \mathrm{t}+\mathrm{Q}_{4} \mathrm{ROAi}, \mathrm{t}+\mathrm{si,t}$

Where:

TAi,t $=$ total accruals in year $\mathrm{t}$ for firm $\mathrm{i}$

$\triangle \mathrm{REVi}, \mathrm{t}=$ revenues in the year $\mathrm{t}$ less revenue in year $\mathrm{t}-1$ for firm i scaled byAi,t-1

PPEi,t $=$ in the year $t$ for the firm i scaled by Ai,t-1

$\mathrm{ROAi}, \mathrm{t}=$ return on assets in the year $\mathrm{t}$ for firm i scaled by Ai,t-1

$\mathrm{Ai}, \mathrm{t}-1=$ total assets in year $\mathrm{t}-1$ for the firm i

$\varepsilon i, \mathrm{t}=$ error term in the year $\mathrm{t}$ for firm

This study used three popular models that is the Jones (1991) the Modified Jones Model by Dechow et al. (1995) and Modified Jones Model by Kothari et al. (2005) to detect earnings management in listed firms on HOSE.

\subsubsection{Data Collection}

Data is collected from the annual financial reports between 2013-2015 from 300 nonfinancial companies listed on HOSE from the website cophieu68.vn.

\subsubsection{Models Standardized for Controlling Heteroskedasticity}

To reduce the heteroskedasticity, three models are standardized by dividing all their components by total asset (Ai,t-1). The standardized models expressed as below:

- Jones (1991):

TAi,t $/$ Ai,t $-1=\beta_{0}(1 /$ Ai,t -1$)+\beta_{1} \Delta$ REVi,t $/$ Ai,t $-1+\beta_{2}$ PPEi,t $/$ Ai,t $-1+$ si,t

- Modified Jones Model by Dechow et al. (1995):

$\mathrm{TAi}, \mathrm{t} / \mathrm{Ai}, \mathrm{t}-1=\beta_{0}(1 / \mathrm{Ai}, \mathrm{t}-1)+\beta_{1}(\Delta \mathrm{REVi}, \mathrm{t}-\Delta \mathrm{RECi}, \mathrm{t})+\beta_{2}$ PPEi,t $+\varepsilon \mathrm{i}, \mathrm{t}$

- Modified Jones Model by Kothari et al. (2005)

TAi,t $/$ Ai,t-1 $=\beta_{0}(1 /$ Ai,t -1$)+\beta_{1} \Delta$ REVi, $t+\beta_{2}$ PPEi, $t+\beta_{3}$ ROAi, $t+$ si,t

\subsubsection{Measuring Earnings Management}

Earnings management is assumed to be the act of manipulating accruals. Accruals could be either an impression of earnings manipulation or just usual accounting measures based on the expectations of business in the future. It is not easy to identify which one would affect accruals. However, it was proven that the size of accruals could be employed as a harsh measurement for manipulating earnings, especially companies with high-accrual.

To determine the total net accruals estimated in a specific period of time, we must subtract the cash earnings from the accruals earning for the period. There are two approaches using: the balance sheet or the cash-flow statement in order to calculate the total net accruals hidden in the reported earnings. In this study the balance sheet method was used to process the measurement of total accrual, and the total net accruals can be estimated as below:

Total accruals = Accrual Earnings + Cash Earnings (1)

Apparently, accrual earnings and cash earnings are not presented in the balance sheet, to retrieve this information, further calculation must be performed.

Step 1: Estimating Accrual Earnings

Net income appears in the balance sheet as retained earnings, which serves as a part of owners' equity. Moreover, the net distribution to equity holder is demonstrated by owners' equity, thus this item should be modified. Therefore, the owners' equity will be estimated as the equation below:

Ending equity = Beginning equity - cash dividends - stock repurchases + equity issuance

To estimate accrual earnings, the above formula can be rearranged to identify the difference between ending owners' equity and beginning owners' equity, and then adjusting it with stock repurchases, dividends, and stock issuances. This adjustment represents the net cash distributions to equity.

Accrual Earnings (AE) =? Owner Equity + Cash Dividend + Stock Repurchases - Equity Issuance

$\mathrm{AE}=$ ? Owner Equity + Net Cash Distribution to Equity

Now, assuming that Assets - Liabilities = Owners' Equity, we can substitute in to get the following equation for accrual earnings:

Accrual Earnings =? Assets - ? Liabilities + Net Cash Distribution to Equity (2) 
Step 2: Estimating Cash Earnings

To start, cash earning have a relation with cash account and can be determined by looking at the changes. Moreover, net cash distributions to equity holders also have influence on cash account, and these items need to be adjusted. Therefore, at the end of the period, cash earnings will be:

Cash Earnings $=$ ? Cash + Cash Dividend + Stock Repurchase - Equity Issuance $=$ ? Cash + Net Distribution to Equity (3)

Step 3: Estimating Total Net Accruals

From (1), (2), (3) we have:

Total Net Accruals = Accrual Earnings - Cash Earning

$=($ ? Assets - ? Liabilities - Net Cash Distribution to Equity $)-($ ? Cash + Net Cash Distribution to Equity $)$

The net cash distributions to equity eliminate each other out, and the equation reduces to:

Total Net Accruals =? Assets -? Liabilities - ? Cash

\section{Results}

\subsection{Ordinary Least Square Regression}

Table-1. OLS regression results

\begin{tabular}{l|l|l}
\hline Jones (1991) & Coefficients & p-value \\
\hline 1/Ai,t-1 & .720 & 0.000 \\
\hline$\Delta \mathrm{REVi}, \mathrm{t} / \mathrm{Ai}, \mathrm{t}-1$ & -.261 & 0.000 \\
\hline PPEi,t /Ai,t-1 & -.124 & 0.012 \\
\hline Patricia et al. $(\mathbf{1 9 9 5 )}$ & Coefficients & -value \\
\hline 1/Ai,t-1 & 788 & 0.000 \\
\hline$\Delta \mathrm{REVi}, \mathrm{t}-\Delta \mathrm{RECi}, \mathrm{t}) / \mathrm{Ai}, \mathrm{t}-1$ & .055 & 0.170 \\
\hline PPEi,t /Ai,t-1 & -.317 & 0.000 \\
\hline Kothari et al. $(\mathbf{2 0 0 5})$ & Coefficients & p-value \\
\hline 1/Ai,t-1 & .717 & 0.000 \\
\hline$\Delta \mathrm{REVi}, \mathrm{t} / \mathrm{Ai}, \mathrm{t}-1$ & -.269 & 0.000 \\
\hline PPEi,t /Ai,t-1 & -.151 & 0.010 \\
\hline ROAi,t /Ai,t-1 & .850 & 0.396
\end{tabular}

The results shows that two variables $(\triangle \mathrm{REVi}, \mathrm{t} / \mathrm{Ai}, \mathrm{t}-1$ and PPEi,t /Ai,t-1), significantly, explains the variance of total net accruals of the 3 models (see Table 1). Adjusted R-square of all three models is rather higher (Table 2) hence, all three models can be applied to detect earnings management of firms.

\begin{tabular}{l|l|l}
\multicolumn{3}{c}{ Table-2. Adjusted R-Square of 3 models } \\
\hline Model & Adjusted R $\mathbf{R}^{2}$ & p-value \\
\hline Jones (1991) & 0.618 & .000 \\
\hline Patricia et al. $(1995)$ & 0.582 & .000 \\
\hline Kothari et al. $(2005)$ & 0.617 & .000 \\
\hline Source: Calculated by authors from Eview 8
\end{tabular}

\subsection{Multicollinearity Test}

If "multicollinearity" appeared, in which two certain independent variables themselves create a linear relation with each other, then the results generated by regressions will be biased. Therefore we tested for multicollinearity and the test results presented in Table 3.

\begin{tabular}{l|l}
\multicolumn{2}{c}{ Table-3. Detecting multicollinearity } \\
\hline Jones (1991) & Variance Inflation Factor(VIF) \\
\hline 1/Ai,t-1 & 1.218 \\
\hline$\Delta \mathrm{REVi}, \mathrm{t} / \mathrm{Ai}, \mathrm{t}-1$ & 1.726 \\
\hline PPEi,t /Ai,t-1 & 1.866 \\
\hline Patricia et al. (1995) & VIF \\
\hline 1/Ai,t-1 & 1.100 \\
\hline$\Delta \mathrm{REVi,t}-\Delta \mathrm{RECi}, \mathrm{t}) / \mathrm{Ai}, \mathrm{t}-1$ & 1.123 \\
\hline PPEi,t /Ai,t-1 & 1.184 \\
\hline Kothari et al. $(\mathbf{2 0 0 5})$ & $V I F$ \\
\hline $1 / \mathrm{Ai}, \mathrm{t}-1$ & 1.228 \\
\hline$\Delta \mathrm{REVi}, \mathrm{t} / \mathrm{Ai}, \mathrm{t}-1$ & 1.785 \\
\hline PPEi,t / Ai,t-1 & 2.642 \\
\hline ROAi,t / Ai,t-1 & 2.144 \\
\hline Source: $\mathrm{Calculated}$ by authors from Eview 8 &
\end{tabular}

The variance inflation factors (VIF) of all predictors in the three models are lower than 10, therefore we conclude that there are no the existence of multicollinearity in all three models.

\subsection{Autocorrelation Test}

To detect the existence of autocorrelation in the model Durbin-Watson test was used and the test's results shown in Table 4 


\begin{tabular}{l|l}
\multicolumn{2}{c}{ Table-4. Durbin-Watson test result } \\
\hline Models & Durbin-Watson test \\
\hline Jones (1991) & 1.841 \\
\hline Patricia et al. $(1995)$ & 1.839 \\
\hline Kothari et al. (2005) & 1.838 \\
\hline Source: Calculated by authors from Eview 8
\end{tabular}

In Durbin-Watson test, there are 2 critical values, an upper critical value $(\mathrm{dU})$ and a lower critical value $(\mathrm{dL})$. There is also an intermediate region where we can neither reject nor accept Ho.

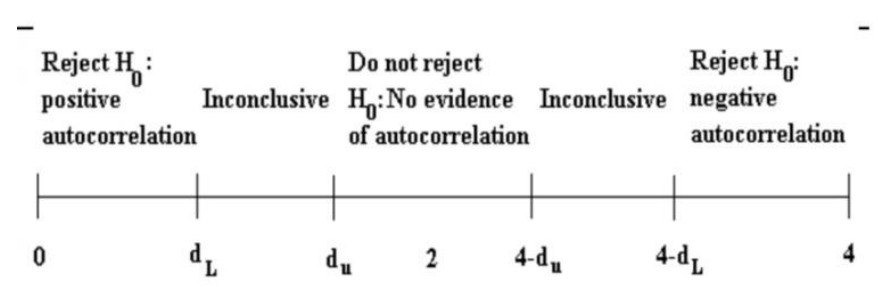

Table-5. Durbin Watson critical values

\begin{tabular}{l|l|l|l}
\hline Models & Lower critical value $(\mathrm{dL})$ & Test statistic & Upper critical value (dU) \\
\hline Jones (1991) & 1.79051 & 1.841 & 1.83088 \\
\hline Patricia et al. $(1995)$ & 1.79051 & 1.839 & 1.83088 \\
\hline Kothari et al. $(2005)$ & 1.78371 & 1.838 & 1.83773 \\
\hline
\end{tabular}

Source: Calculated by authors from Eview 8

Table-6. Durbin Watson critical values

\begin{tabular}{l|l|l|l}
\hline Models & dU & Test statistic & 4-dU \\
\hline Jones (1991) & 1.83088 & 1.841 & 2.16912 \\
\hline Patricia et al. $(1995)$ & 1.83088 & 1.839 & 2.16912 \\
\hline Kothari et al. $(2005)$ & 1.83773 & 1.838 & 2.16227 \\
\hline
\end{tabular}

The test statistics of all three models are greater than upper critical values $(\mathrm{d} U)$ and smaller than $4-\mathrm{dU}$. So we do not reject the null hypothesis that there is no evidence of autocorrelation in models.

\subsection{White Test for Heteroskedasticity}

Table-7. White test results

Heteroskedasticity Test: White

\begin{tabular}{lrll}
\hline \hline F-statistic & 983.4756 & Prob. F $(9,289)$ & $\mathbf{0 . 0 0 0 0}$ \\
Obs*R-squared & 289.5461 & Prob. Chi-Square(9) & $\mathbf{0 . 0 0 0 0}$ \\
Heteroskedasticity Test: White & & \\
\hline \hline & & & $\mathbf{0 . 0 0 0 0}$ \\
F-statistic & 1953.834 & Prob. F $(9,287)$ & $\mathbf{0 . 0 0 0 0}$ \\
Obs*R-squared & 292.2305 & Prob. Chi-Square(9) & \\
Heteroskedasticity Test: White & & $\mathbf{0 . 0 0 0 0}$ \\
\hline \hline & & & $\mathbf{0 . 0 0 0 0}$
\end{tabular}

White test resulted in the rejection of null hypothesis, implying the presence of heteroskedasticity in the models.

\subsection{Treatment for Heteroskedasticity}

Table-8. Treatment results

\begin{tabular}{l|l|l}
\hline Jones (1991) & Coefficients & p-value \\
\hline 1/Ai,t-1 & -4966.937 & 0.0098 \\
\hline$\Delta \mathrm{REVi}, \mathrm{t} / \mathrm{Ai}, \mathrm{t}-1$ & .058324 & 0.0000 \\
\hline PPEi,t /Ai,t-1 & .019393 & $\mathbf{0 . 0 8 6 5}$ \\
\hline Patricia et al. $(1995)$ & Coefficients & p-value \\
\hline 1/Ai,t-1 & -3754.492 & $\mathbf{0 . 0 5 0 8}$ \\
\hline$\Delta \mathrm{REVi}, \mathrm{t}-\Delta \mathrm{RECi}, \mathrm{t}) / \mathrm{Ai}, \mathrm{t}-1$ & $1.71 \mathrm{E}-\mathrm{O} 5$ & $\mathbf{0 . 5 9 2 2}$ \\
\hline PPEi,t /Ai,t-1 & -.317 & $\mathbf{0 . 1 1 2 7}$ \\
\hline Kothari et al. $(2005)$ & Coefficients & -value \\
\hline 1/Ai,t-1 & -4756.989 & 0.0118 \\
\hline$\Delta \mathrm{REVi}, \mathrm{t} / \mathrm{Ai}, \mathrm{t}-1$ & .055435 & 0.0000 \\
\hline PPEi,t /Ai,t-1 & .014489 & $\mathbf{0 . 2 7 1 1}$ \\
\hline ROAi,t /Ai,t-1 & 46734.9 & 0.0000
\end{tabular}

Source: Calculated by authors from Eview 8 
Through the tests of heteroskedasticity, we can see that Jones (1991) and Modified Jones model by Kothari et al. (2005) have better performance than the Modified Jones Model by Patricia et al. (1995).

\section{Discussion}

The three models have closely the same the adjusted R2. However, Jones (1991) and Modified Jones by Kothari et al. (2005) outperform the Modified Jones model by Patricia et al. (1995). Firm manager makes the decision to manage not only sale revenues but also costs and expenses in the financial reporting. For that reasons, if we do not include costs and expenses, it might not fully represent the characteristics of current accrual. The poor explanatory power of model may be resulted from not including expenses. Due of this reason, we might recognize that the relationship between total accruals and current accruals is imbalanced because the models cannot present a suitable and applicable explanation for the relationship. In short, managers are able to select between account receivable and account payable to manage earnings.

Using PPE as a proxy for noncurrent accruals is relatively appropriate, but PPE may not be effective enough to represent the real characteristics of noncurrent accruals. The component that should have been acknowledged is intangible assets because General Accepted Accounting Principle rules stated that intangible asset investments be recorded as expenses in the period they have occurred (International Accounting Standards Boards, 2010). For that reason, the model must include additional proxy to represent the intangible assets.

\section{Conclusion}

This study provided the understanding on how firms manipulate actual earning revealing earning management in Vietnamese firms. The study also analyzed the effectiveness of the three most well-known models, and to examine how fit of those models in the context of Vietnam. The research's result demonstrated that Jones Model is shown as better measurement in case of effectiveness and explanatory power of selected proxies to detect the act of manipulating earning.

However, the outcome would be more accurate if the intangible asset variable was added to develop a new model. Identifying the act of earning management is useful for not only investors but also financial analysts to have a deep understanding about the characteristics of emerging stock market like Vietnam market, thus there will be more accurate and efficient in making investment decisions. In turn, the operating performance of companies may be dramatically improved.

\section{References}

Bhojraj, S., P. Hribar, M. Picconi and J. McInnis, 2009. Making sense of cents: An examination of firms that marginally miss or beat analyst forecasts. Journal of Finance, 64(5): 2361-2388. View at Google Scholar $\mid$ View at Publisher

Burns, W.J.J. and K.A. Merchant, 1990. The dangerous morality of managing earnings. Management Accounting, 72(2): 22-25. View at Google Scholar

DeAngelo, H., L. DeAngelo and D.J. Skinner, 1994. Accounting choice in troubled companies. Journal of Accounting and Economics, 17(1): 113- 143. View at Google Scholar | View at Publisher

DeAngelo, L.E., 1986. Accounting numbers as market valuation substitutes: A study of management buyouts of public stockholders. Accounting Review, 61(3): 400-420. View at Google Scholar

Dechow, P.M., R.G. Sloan and A.P. Sweeney, 1995. Detecting earnings management. Accounting Review, 70(2): 193-225. View at Google Scholar

Grant, C.T., C.M.J. Depree and G.H. Grant, 2000. Earnings management and the abuse of materiality. Journal of Accountancy, 190(3): 4144. View at Google Scholar

Healy, P.M., 1985. The effect of bonus schemes on accounting decisions. Journal of Accounting and Economics, 7(1-3): 85-107. View at Google

Scholar $\mid$ View at Publisher
Healy, P.M. and J.M. Wahlen, 1999. A review of the earnings management literature and its implications for standard setting. Accounting Horizons, 13(4): 365-383. View at Google Scholar | View at Publisher

International Accounting Standards Boards, 2010. Conceptual Framework for Financial Reporting. London: International Accounting Standards Board (IASB), 2010. Retrieved from http://www.ifrs.org/News/Press-Releases/Documents/ConceptualFW2010vb.pdf.

Jones, J.J., 1991. Earnings management during import relief investigations. Journal of Accounting Research, 29(2): 193-228. View at Google Scholar $\mid$ View at Publisher

Kothari, S.P., A.J. Leone and C.E. Wasley, 2005. Performance matched discretionary accrual measures. Journal of Accounting and Economics, 39(1): 163-197. View at Google Scholar | View at Publisher

Patricia, M.D., R.G. Sloan and A.P. Sweeney, 1995. Detecting earnings management. Accounting Review, 70(2): 193-225. View at Google Scholar

Ronen, J. and V. Yaari, 2008. Earnings management: Emerging insights in theory, practice, and research. New York: Springer Science+Business Media.

White, H., 1980. A heteroskedasticcity - consistent covariance matrix estimator and a direct test for heteroskedasticity. Econometrica, 48(4): 817-838. View at Google Scholar | View at Publisher

\section{Bibliography}

Dechow, P.M., 1994. Accounting earnings and cash flows as measures of firm performance: The role of accounting accruals. Journal of Accounting and Economics, 18(1): 3-42. View at Google Scholar $\mid$ View at Publisher

Dechow, P.M., S.P. Kothari and R.L. Watts, 1998. The relation between earnings and cash flows. Journal of Accounting and Economics, 25(2): 133-168. View at Google Scholar | View at Publisher 